Article

\title{
Long-Term Impact of Living and Learning at High Altitude: An Altitude Physiology Class for Undergraduate Students
}

\author{
Maurie J. Luetkemeier*(D), John E. Davis and J. Brian Hancock II (D) \\ Department of Integrative Physiology and Health Science, Alma College, Alma, MI 48801, USA; \\ davisj@alma.edu (J.E.D.); hancockb@alma.edu (J.B.H.II) \\ * Correspondence: luetkemeier@alma.edu
}

\begin{abstract}
Alma College initiated an Altitude Physiology class in 1997 devoted to living and learning at high altitude $(3440 \mathrm{~m})$. The class incorporated several key elements of High-Impact Educational Practice including a strong student-research component and collaborative groups assignments. A retrospective survey was administered to alumni of the class to determine its long-term impact. Student responses ranged from "agree" to "strongly agree" with statements regarding the class's impact on positive learning outcomes such as critical thinking, knowledge acquisition, synthesis of knowledge, and understanding of research. Students generally favored non-traditional formats such as living at altitude for gaining understanding of environmental physiology.
\end{abstract}

Keywords: high-impact; altitude; physiology; environmental

\section{Introduction}

Trekking from sea level to high altitude causes a cascade of physiological challenges Citation: Luetkemeier, M.J.; Davis, J.E.; Hancock II, J.B. Long-Term Impact of Living and Learning at High Altitude: An Altitude Physiology Class for Undergraduate Students. Educ. Sci. 2022, 12, 112. https://doi.org/10.3390/ educsci12020112

Academic Editor: Shawn R. Simonson

Received: 6 October 2021 Accepted: 14 December 2021 Published: 7 February 2022

Publisher's Note: MDPI stays neutral with regard to jurisdictional claims in published maps and institutional affiliations.

Copyright: (C) 2022 by the authors. Licensee MDPI, Basel, Switzerland. This article is an open access article distributed under the terms and conditions of the Creative Commons Attribution (CC BY) license (https:// creativecommons.org/licenses/by/ $4.0 /)$. all stemming from the reduction in barometric pressure and the ensuing decrease in the partial pressure of oxygen. The reduced oxygen availability compromises one's ability to deliver oxygen to the tissues, causing heart rate and ventilatory volume to increase while adversely affecting mood, exercise tolerance, and overall well-being. However, over time, individuals acclimatize to continued high-altitude exposure by expanding red blood cell volume, boosting hematocrit and hemoglobin levels, and thereby providing the tissues with more oxygen. Athletes have attempted to capitalize on this adaptation by living at high altitude for several weeks prior to athletic competition while maintaining high-intensity training at lower altitude, i.e., live high/train low [1,2]. Likewise, a similar strategy has been proposed for astronauts to prepare for extravehicular activity (EVA) during space flight $[3,4]$.

While it is one thing to lecture students in a classroom about how the human body responds and ultimately adapts to this unique environment, it is quite another thing to take students to high altitude and let them experience these changes for themselves [5]. Such was the intent of Harper and Webster [6], who took a group of college-aged students on an expedition to the highlands of Bolivia (>4000 m) for 3 weeks. They documented the expected deleterious short-term effects of altitude on oxygen saturation and acute mountain sickness as well as cognitive and visual reaction times. However, they also reported positive outcomes pertaining to personal growth, resilience, teamwork, and environmental awareness. Outward Bound ${ }^{\mathrm{TM}}$ and other expedition-style programs have demonstrated similar substantial gains in diverse outcomes such as self-concept, locus of control, and leadership [7]. The literature involving expedition-style educational experiences was reviewed by Stott [8], who characterized the student outcomes into a model of personal development based on Greenaway's four-part simplified development framework of potential growths [9]: upward growth (realizing potential), outward growth (learning about others), inward growth (learning about self), and downward growth (learning about the 
environment). Table 1 depicts examples adapted from Stott's work regarding directions for potential growth associated with participation in an expedition-style educational experience. Similar outcomes have been widely reported by other outdoor adventure programs covering a diverse variety of adventure modes [10-15].

Table 1. Personal development outcomes associated with expedition-style experiences for youth and emerging adults.

\begin{tabular}{l} 
Upward Growth-Increased Confidence, Physical and Social Resilience, Self-Reliance, and Ability \\
to Overcome \\
Challenges \\
\hline Outward growth-Improved social skills, leadership capacity \\
\hline Inward growth-Improved emotional stability and ability to reflect on events \\
\hline Downward growth-Increased environmental appreciation and awareness \\
Source: Adapted from Stott et al. [8] (Reprinted with permission from Copyright Owner: Taylor \& Francis, \\
Copyright Year: 2015).
\end{tabular}

In 1997, Alma College launched its first Altitude Physiology class, which took a group of students from Alma, Michigan $(224 \mathrm{~m}$ ) to the 10th Mountain Division Huts near Vail, Colorado to experience 3 weeks at high altitude $(3440 \mathrm{~m})$. The Altitude Physiology class was under the direction of Dr. John Davis, who designed the class as an outdoor educational experience that incorporated other high-impact educational practices [16]. Over the next 18 years, Dr. Davis, along with several faculty colleagues, led ten Altitude Physiology classes and thereby provided a vibrant and impactful experience for 150 Alma College students. In the following sections, we will describe the foundational theories that guided the course as well as the academic structure at Alma College that permitted an extended time away from campus. We will also describe the research methods employed to determine the long-term impact of the class on critical thinking, teamwork, research methods, and understanding physiology.

Theoretical Framework: The theoretical framework for the Altitude Physiology class was based on educational practices known as "High-Impact". The Association of American Colleges and Universities identified 10 key elements known collectively as High-Impact Educational Practices that "have been widely tested and have shown to benefit college students from many backgrounds [16]." The Altitude Physiology class was designed to incorporate at least two of these key elements, i.e., (1) collaborative assignments and projects and (2) undergraduate research.

The first of these key elements was initiated during introductory meetings beginning in January, in which students were organized into collaborative groups of two or three students. Over the next 3 months, each group was expected to review relevant literature on altitude physiology and determine a physiological response or adaptation that they wanted to further explore, i.e., a real problem. They then proposed a research project that they could conduct on themselves and their classmates. These projects were presented to the total group of students and faculty for critique and revision. An overall structure was imposed on these research projects that included four data collections: at sea level before departure (sea level 1), at altitude immediately upon arrival (Altitude 1), at altitude following 16 days of acclimation (Altitude 2), and, finally, immediately upon return to sea level (Sea Level 2). Once these projects were finalized, faculty and students brainstormed regarding "if" and "how" individuals could participate in one another's group research project without contaminating the results. For example, if a subject was expected to perform sprint exercise in one study, they could not also perform resting data in another study without considering the rest interval between the two studies.

The second key element focused on the student research itself. Students were expected to conduct the research using best practices for data collection, data management, data interpretation, and synthesis. Students coordinated scheduling with each other and were ultimately responsible for the quality of their research projects. Once all four data 
collections were completed, each group was responsible for analyzing and presenting the findings of their projects during a final research seminar. Many of the projects were also presented at Alma College's Honors Day research symposium as well as at regional and national conferences.

In addition to engaging in authentic aspect of disciplinary research, once in Colorado the class met daily to discuss the responses and adaptations that characterize living at high altitude all the while living at high altitude and experiencing those same responses and adaptations. The theory grounding this approach was based on active immersion into the environment, which we anticipated would promote greater appreciation of the physiological challenges [5,17]. Plenty of time was reserved for hiking and snowshoeing on the many trails located around the huts, and one goal of every class was to climb the 4348 m peak of Mt. Quandary located near our base camp (see Figure 1). These adventurous outdoor challenges were included not only for enjoyment but also to facilitate teamwork and collaboration $[10,11]$.

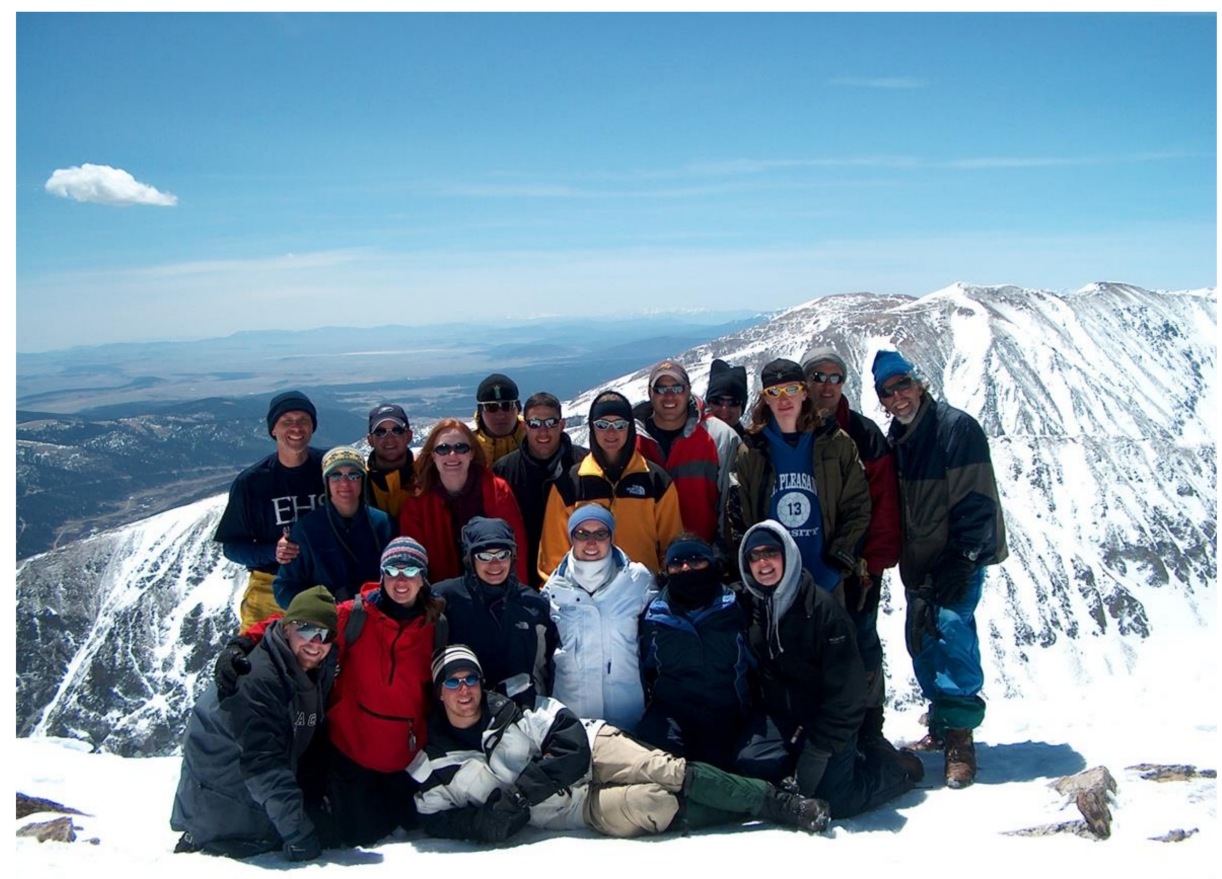

Figure 1. Students and Faculty at the summit of Mt. Quandary, Colorado (4348-meters). (Copyright Year: 2003, Copyright Owner: Alma College, Alma, MI, USA).

Academic Structure at Alma College: Alma College is a private liberal arts college in Alma, Michigan located in the middle of the lower peninsula. It serves 1400 undergraduate students in a residential learning atmosphere. At Alma College, the month of May is designated as a "spring term" in which students enroll in one 4-credit class for approximately 3.5 weeks. This unique format allows students to travel off campus to experience different environments and cultures such as the Altitude Physiology class. Given that many students entering Alma College have not left the United States or even the state of Michigan, this spring-term structure provides an important opportunity to broaden students' experiences.

The Altitude Physiology class attracted students primarily intent on pursuing graduate school in some healthcare-related field such as medicine, physical therapy, occupational therapy, or physician's-assistant training. The majority of students enrolled in Altitude Physiology during their sophomore or junior years after having completed two semesters of human physiology, as well as one semester each of human anatomy and exercise physiology. 


\section{Materials and Methods}

As part of the investigation of the long-term impact of Altitude Physiology on the students following graduation, the authors conducted a survey of all 150 students who participated in any one of the sections of the class from 1997 to2014. The survey was designed following discussion among the authors along with adapting some items from surveys with similar overall intent [18]. The final version of the Qualtrics-based survey was composed of 20 items that included demographic information along with statements allowing students to indicate their level of agreement on statements using a five-point Likert scale. Following the statements, students were given an opportunity to write an open-ended comment to further clarify their responses. The survey was reviewed and approved by the Institutional Review Board of Alma College prior to its distribution.

The authors requested current contact information for all 150 past Altitude Physiology participants from Alma College's alumni office. This yielded 105 email addresses, all of whom were sent the survey in November, 2020. Five of the emails were returned as inactive, thus, the survey was actually sent to 100 participants, which, composed the study population. However, it is unknown whether all 100 participants actually engaged with these email addresses and received the survey. Therefore, it is possible that the study population of $n=100$ was inflated. We received 36 responses from students who answered at least one survey item, representing $24 \%$ (36 of 150) of the total population and 36\% (36 of 100) of the study population. Each section of the class from 1997 and 2014 was represented by at least one respondent with an average interval of $14.7 \pm 5.5$ years between completing the class and responding to the survey. Overall, 20 of the responders were female $(56 \%)$ while $16(44 \%)$ were male. The responders represented a variety of academic majors but were primarily Integrative Physiology and Health Science majors, which was the academic department of the faculty. In an effort to determine background information about the respondents, the students were asked "What prompted you to enroll in Altitude Physiology?" Respondents were allowed to choose more than one answer and $31 \%$ indicated that they were "interested in the subject matter", $26 \%$ noted they were "interested in travel", and another $26 \%$ said that they were "fulfilling a spring term requirement". Other responses included "upper-division credit hours" ( $8 \%)$, and "potential connection to future careers" $(8 \%)$.

\section{Results}

The statements in Table 2 were posed to the participants and their responses were indicated using a five-point Likert scale with $5=$ strongly agree, $4=$ agree, $3=$ neither agree nor disagree, 2 = disagree, 1 = strongly disagree.

The participants were invited to write comments to clarify their responses and 17 of the 36 students chose to do so. The authors first investigated, separately, small portions of the data guided by a priori codes from previous literature on High-Impact teaching practices and expedition-style programs $[7,8,16]$. Subsequently, they met to discuss similarities and differences and found, from this coding experience, that important themes emerged. The authors then analyzed the frequency of these themes and presented those results in the followed section. A single student's comment often referred to more than one theme, in which case all references were counted. The five common themes that evolved, in the order of frequency cited, were (1) research, (2) impact of the experience on future career, (3) physiology knowledge, (4) critical thinking, and (5) cooperative teamwork. These emergent themes from the data represented refinements and expansions of the AACU's "High-Impact" educational practices (16) that guided our course development (i.e., collaborative assignments and projects and undergraduate research). 
Table 2. Responses from students to statements posed in the survey (Set 1).

\begin{tabular}{|c|c|c|c|c|c|c|c|c|c|c|c|}
\hline $\begin{array}{l}\text { The Altitude Physiology } \\
\text { Course Impacted My } \\
\text { Ability to ... }\end{array}$ & 5 & 4 & 3 & 2 & 1 & Max & Min & Mean & S.D. & Var & Count \\
\hline $\begin{array}{l}\ldots \text { Think critically and } \\
\text { formulate my own ideas. }\end{array}$ & $\begin{array}{c}18 \\
50 \%\end{array}$ & $\begin{array}{c}14 \\
39 \%\end{array}$ & $\begin{array}{c}3 \\
8 \%\end{array}$ & $\begin{array}{c}1 \\
3 \%\end{array}$ & $\begin{array}{c}0 \\
0 \%\end{array}$ & 5 & 2 & 4.36 & 0.75 & 0.56 & 36 \\
\hline $\begin{array}{l}\text {... Communicate more } \\
\text { effectively with my } \\
\text { professional colleagues. }\end{array}$ & $\begin{array}{c}19 \\
54 \%\end{array}$ & $\begin{array}{c}15 \\
43 \%\end{array}$ & $\begin{array}{c}1 \\
3 \%\end{array}$ & $\begin{array}{c}0 \\
0 \%\end{array}$ & $\begin{array}{c}0 \\
0 \%\end{array}$ & 5 & 3 & 4.51 & 0.55 & 0.31 & 35 \\
\hline $\begin{array}{l}\text {... Integrate and } \\
\text { synthesize knowledge about } \\
\text { physiological concepts. }\end{array}$ & $\begin{array}{c}25 \\
71 \%\end{array}$ & $\begin{array}{c}10 \\
29 \%\end{array}$ & $\begin{array}{c}0 \\
0 \%\end{array}$ & $\begin{array}{c}0 \\
0 \%\end{array}$ & $\begin{array}{c}0 \\
0 \%\end{array}$ & 5 & 4 & 4.71 & 0.45 & 0.20 & 35 \\
\hline $\begin{array}{l}\text {.. Appreciate how } \\
\text { research is formulated and } \\
\text { conducted. }\end{array}$ & $\begin{array}{c}29 \\
83 \%\end{array}$ & $\begin{array}{c}6 \\
17 \%\end{array}$ & $\begin{array}{c}0 \\
0 \%\end{array}$ & $\begin{array}{c}0 \\
0 \%\end{array}$ & $\begin{array}{c}0 \\
0 \%\end{array}$ & 5 & 4 & 4.83 & 0.38 & 0.14 & 35 \\
\hline $\begin{array}{l}\text {... Understand how } \\
\text { research is presented to the } \\
\text { scientific community. }\end{array}$ & $\begin{array}{c}22 \\
65 \%\end{array}$ & $\begin{array}{c}11 \\
32 \%\end{array}$ & $\begin{array}{c}1 \\
3 \%\end{array}$ & $\begin{array}{c}0 \\
0 \%\end{array}$ & $\begin{array}{c}0 \\
0 \%\end{array}$ & 5 & 3 & 4.62 & 0.54 & 0.29 & 34 \\
\hline $\begin{array}{l}\text {... Integrate and } \\
\text { synthesize knowledge from } \\
\text { multiple disciplines. }\end{array}$ & $\begin{array}{c}19 \\
54 \%\end{array}$ & $\begin{array}{c}13 \\
37 \%\end{array}$ & $\begin{array}{c}3 \\
9 \%\end{array}$ & $\begin{array}{c}0 \\
0 \%\end{array}$ & $\begin{array}{c}0 \\
0 \%\end{array}$ & 5 & 3 & 4.45 & 0.65 & 0.42 & 35 \\
\hline
\end{tabular}

The theme that was cited most frequently referred to an understanding of how research was conducted. This theme was expressed by 15 of 17 students $(88 \%)$. Yet only one student commented on the importance of the specific content of their research. The following quote characterizes comments pertaining to the research theme.

"We experienced how real research is conducted and went through the entire process from literature review, developing a problem to solve, methods to solve the problem, analyzing results, and coming to conclusions."

Five of those participants who commented on research also noted the importance of presenting their research at a regional or national conference. For example, another respondent added:

"Through this spring term my group of four split the project into two abstracts where we were able to present our findings in an oral presentation at the Alma College Honors Day and the Michigan American College of Sports Medicine (ACSM) meeting and further we were able to present the findings to the national ASCM meeting in San Diego."

The second most often cited theme (9 of 17, 53\%) involved how the Altitude Physiology class influenced some aspect of their ultimate career. For example, one student wrote,

"One of the most impactful experiences in my college career. It (and getting to present data from this class at a conference) was one of the big experiences that helped me shift away from my plan to be a math teacher to wanting to pursue a graduate degree in exercise physiology."

Seven students (41\%) commented on how the Altitude Physiology class increased their understanding of physiology. Of those seven, four commented specifically about their knowledge of altitude physiology. One student noted:

"My understanding of altitude physiology translated to a deep, lasting understanding of respiratory physiology. I have thought back to this class during my first year of medical school and even more recently on my ICU rotations."

The final two themes were cited by five students each (29\%) and involved the requirement to (1) employ critical thinking skills to solve complex problems, as well as (2) to 
engage in collaborative teamwork for the completion of projects and assignments. These two themes were characterized by the following comments.

"Every project had to deal with challenges given the changes in the environment, which could have altered the study's results during each testing phases. Having to think of ways to conduct the studies to keep the testing as accurate as possible and having to explain those changes in a paper, shows how challenging it is to do research in the field rather than in a standard lab setting."

"The study teams of two made for a good balance of individual responsibility and teamwork. Also, the entire group was a larger team that helped each other learn and problem solve."

The next two sets of statements were posed to the respondents, asking them to compare high-impact teaching classes such as Altitude Physiology with more traditional classroom experiences. Responses to these statements were again rated using a five-point Likert scale with $5=$ significant positive impact, $4=$ positive impact, $3=$ neither positive nor negative impact, 2 = negative impact, 1 = significant negative impact. (see in Table 3 ).

Table 3. Responses from students to statements posed in the survey (Sets $2 \& 3$ ).

\begin{tabular}{|c|c|c|c|c|c|c|c|c|c|c|c|}
\hline $\begin{array}{l}\text { Compared to Other More } \\
\text { Traditional } \\
\text { Classroom Experiences, } \\
\text { Altitude Physiology } \\
\text { Impacted My Ability to ... }\end{array}$ & 5 & 4 & 3 & 2 & 1 & Max & Min & Mean & S.D. & Var & Count \\
\hline $\begin{array}{l}\text {... Recognize the physical } \\
\text { requirements posed by a } \\
\text { demanding environment } \\
\text { condition. }\end{array}$ & $\begin{array}{c}29 \\
83 \%\end{array}$ & $\begin{array}{c}5 \\
3 \%\end{array}$ & $\begin{array}{c}1 \\
3 \%\end{array}$ & $\begin{array}{c}0 \\
0 \%\end{array}$ & $\begin{array}{c}0 \\
0 \%\end{array}$ & 5 & 3 & 4.80 & 0.47 & 0.22 & 35 \\
\hline $\begin{array}{l}\text {... Grasp how my body } \\
\text { reacts and adapts to } \\
\text { environmental challenges. }\end{array}$ & $\begin{array}{c}27 \\
77 \%\end{array}$ & $\begin{array}{c}7 \\
20 \%\end{array}$ & $\begin{array}{c}1 \\
3 \%\end{array}$ & $\begin{array}{c}0 \\
0 \%\end{array}$ & $\begin{array}{c}0 \\
0 \%\end{array}$ & 5 & 3 & 4.74 & 0.50 & 0.25 & 35 \\
\hline $\begin{array}{l}\text {... Understand } \\
\text { physiological concepts. }\end{array}$ & $\begin{array}{c}23 \\
66 \%\end{array}$ & $\begin{array}{c}12 \\
34 \%\end{array}$ & $\begin{array}{c}0 \\
0 \%\end{array}$ & $\begin{array}{c}0 \\
0 \%\end{array}$ & $\begin{array}{c}0 \\
0 \%\end{array}$ & 5 & 4 & 4.66 & 0.47 & 0.23 & 35 \\
\hline $\begin{array}{l}\ldots \text { Develop a desire to be } \\
\text { more physically active. }\end{array}$ & $\begin{array}{c}15 \\
40 \%\end{array}$ & $\begin{array}{c}14 \\
40 \%\end{array}$ & $\begin{array}{c}6 \\
17 \%\end{array}$ & $\begin{array}{c}0 \\
0 \%\end{array}$ & $\begin{array}{c}0 \\
0 \%\end{array}$ & 5 & 3 & 4.26 & 0.73 & 0.53 & 35 \\
\hline $\begin{array}{l}\text { Select the statement that } \\
\text { best describes the level of } \\
\text { impact that Altitude } \\
\text { Physiology had on your... }\end{array}$ & 5 & 4 & 3 & 2 & 1 & Max & Min & Mean & S.D. & Var. & Count \\
\hline $\begin{array}{l}\text {... Overall Alma College } \\
\text { Experience }\end{array}$ & $\begin{array}{c}23 \\
66 \%\end{array}$ & $\begin{array}{c}11 \\
31 \%\end{array}$ & $\begin{array}{c}1 \\
3 \%\end{array}$ & $\begin{array}{c}0 \\
0 \%\end{array}$ & $\begin{array}{c}0 \\
0 \%\end{array}$ & 5 & 3 & 4.64 & 0.54 & 0.29 & 35 \\
\hline $\begin{array}{l}\text {... Aspiration for } \\
\text { advanced education }\end{array}$ & $\begin{array}{c}14 \\
40 \%\end{array}$ & $\begin{array}{c}11 \\
31 \%\end{array}$ & $\begin{array}{c}10 \\
29 \%\end{array}$ & $\begin{array}{c}0 \\
0 \%\end{array}$ & $\begin{array}{c}0 \\
0 \%\end{array}$ & 5 & 3 & 4.11 & 0.82 & 0.67 & 35 \\
\hline ... Choice of a career & $\begin{array}{c}8 \\
23 \%\end{array}$ & $\begin{array}{c}15 \\
43 \%\end{array}$ & $\begin{array}{c}12 \\
34 \%\end{array}$ & $\begin{array}{c}0 \\
0 \%\end{array}$ & $\begin{array}{c}0 \\
0 \%\end{array}$ & 5 & 3 & 3.89 & 0.75 & 0.56 & 35 \\
\hline $\begin{array}{l}\ldots \text { Overall understanding } \\
\text { of human physiology }\end{array}$ & $\begin{array}{c}16 \\
48 \%\end{array}$ & $\begin{array}{c}17 \\
51 \%\end{array}$ & $\begin{array}{c}0 \\
0 \%\end{array}$ & $\begin{array}{c}0 \\
0 \%\end{array}$ & $\begin{array}{c}0 \\
0 \%\end{array}$ & 5 & 4 & 4.48 & 0.50 & 0.25 & 33 \\
\hline
\end{tabular}

Again, the participants were offered an opportunity to elaborate on their responses and 12 of the 36 (33\%) students provided comments. The common themes that emerged from the second set of statements, in the order of frequency, were (1) High-Impact educational methods, (2) Knowledge transfer to career, (3) Understanding of Physiology, (4) Lifelong love of outdoor activity. 
Students were extremely positive about high-impact educational practices incorporated in the Altitude Physiology class. Six of the 12 students (50\%) commented about the value of experiencing the effects of high altitude at the same time as discussing them in the course. For example, one student noted:

"To experience how the body reacts at different altitudes rather than listening to different reactions in a lecture really enhances the quality of the learning process and full understanding of the physiological effects of altitude changes."

Another student added:

"Climbing up Mount Quandary, the higher we got, the harder it got. We not only learned about the oxy-hemoglobin dissociation curve, but we were living it."

One student, however, mentioned the value of prior classroom experiences that prepared them for the experiential learning environment.

"For me, this real "hands on" approach contributed to my learning in a more meaningful way than most traditional courses, although I should acknowledge that the Altitude Physiology hands-on experience was made possible by having 2 years of traditional classroom and lab experience before I took this course (I think these provided a strong, useful base and that I would not have learned nearly as much or had such a positive experience without this strong base/background before going)."

Another common theme that surfaced was how relevant knowledge learned in Altitude Physiology class was to somewhere in their future career. Six of the 12 (50\%) students commented about the connection between something learned in Altitude Physiology and something relevant in their future career. Two students made explicit connection between the Altitude Physiology course and their experience in medical school. One of these students commented:

"I am finishing up my fourth year of medical school. My understanding of physiology has been greatly enhanced from this class. I routinely recall the readings and our research to help me understand the pathophysiology of many respiratory diseases."

Another student added:

"During medical school, my knowledge and experience in the Altitude Physiology course helped me understand concepts around respiration and ventilation, oxygen-carrying capacity of different forms of hemoglobin, etc."

Along the same line, six of the 12 (50\%) students commented how something learned in Altitude Physiology class added relevance to some future study of physiology. For example, one student wrote,

"I very much appreciated how this class allowed me to experience first-hand how the human body reacts to demanding conditions, enhancing my overall understanding of human physiology."

The last common theme involved engagement with the outdoors. Three (25\%) students commented how Altitude Physiology began for them a lifelong love of the outdoors, particularly climbing the Rocky Mountains of Colorado.

"This class ignited my love of climbing Colorado's 14ers. I have climbed five to date, and plan to continue to climb at least one per year for as long as I can. This class was absolutely the most influential of my undergrad and graduate career."

Lastly, the authors were interested in how students' experiences in Altitude Physiology compared to their experiences in other Alma College courses. The students were asked, "How would you rank Altitude Physiology with other classes that you took in College?" Using a five-point Likert scale with $5=$ one of my favorite classes and $1=$ one of my least favorite classes. Of the 35 participants who responded, 28 (80\%) ranked Altitude Physiology as one of their favorite classes, and $7(20 \%)$ ranked it above average. No one ranked Altitude Physiology as average, below average, or one of their least favorite classes. 


\section{Discussion}

Alma College's Altitude Physiology class was an outdoor educational experience located in the pristine wilderness and rugged peaks of the Rocky Mountains. Set at $3440 \mathrm{~m}$, students witnessed first-hand the physiological alterations that characterize rapid ascent to high altitude including headaches, nausea, and limited physical endurance. They took part in a series of peer-led investigations designed to examine the body's responses and adaptions to altitude as well as prepared them for future meaningful research. The students also enjoyed nearly limitless opportunities for hiking, snow-shoeing, and mountain climbing plus adequate time for solitude and reflection. It was theorized that this combination of elements would result in a long-term and lasting impact on students. In general, this theory was supported by our data. Students largely agreed and, in some instances, strongly agreed that the Altitude Physiology class impacted many positive learning outcomes including critical thinking, knowledge acquisition, successful research management, and knowledge synthesis (see Table 2). Specifically, the two statements that dealt with research i.e., ability to appreciate how research is formulated and conducted as well as understand how research is presented to the scientific community scored particularly high. The mean responses to these statements were $4.83 \pm 0.38$ and $4.62 \pm 0.54$, respectively, indicating strong to very strong agreement with these ideas. These data were supplemented by student comments that clearly described their newfound understanding of how research is conducted and how this research spawned new knowledge.

Undergraduate research featured prominently in the planning and development of the class and it appears that students embraced its significance. Undergraduate research has been linked to numerous positive outcomes including an improved undergraduate experience [19], increased academic achievement [20], a higher graduation rate [21], and a greater interest in graduate education as well as STEM careers. Alma College's Altitude Physiology class was structured similar to the class described by Weigle et al. [5], where the students also participated in peer research projects involving some altitude-related response or adaptation. The authors of that study summarized their experience in the following way.

"The students were uniformly enthusiastic about the use of self-directed experimentation to explore the physiology of altitude adaptation and felt that they learned more from this course format than a control group of students felt that they learned from a physiology course taught by the same instructor in the standard classroom/laboratory format."

A take-away from the current study and the one by Weigle et al. is that the inclusion of undergraduate research yields strong positive student learning outcomes.

Another statement from a survey item in Table 2 that drew a particular strong positive reaction was Altitude Physiology course impacted my ability to integrate and synthesize knowledge about physiological concepts. The mean score for this statement was $4.71 \pm 0.45$, indicating robust positive agreement. Similarly, two statements from items in Table 3 ranked high for students' agreement, including: "Compared to other more traditional classroom experiences, Altitude Physiology impacted my ability to (1) recognize the physical requirements posed by a demanding environment condition and (2) Grasp how my body reacts and adapts to environmental challenges." The mean responses for these two statements were $4.80 \pm 0.47$ and $4.74 \pm 0.50$, respectively. These mean values corresponded with a positive to strong positive impact. Taken together, these data demonstrated the impact this experience had on students' understanding of physiology, particularly those aspects that are immediately affected by high altitude such as the respiratory system. These findings are consistent with the concept known as active learning that was advanced by Michael [22] and Goodman [17] in the teaching of physiology. Michael defines active learning as,

"The process of having students engage in some activity that forces them to reflect upon ideas and how they are using those ideas, i.e., the attainment of knowledge by participating or contributing. The process of keeping students mentally, and often physically, active in 
their learning through activities that involve them in gathering information, thinking, and problem solving."

In the case of our Altitude Physiology class, how better for students to learn about the ventilatory effects of hypoxia than to experience changes in their own breathing patterns while hiking up a $>4000 \mathrm{~m}$ mountain with a loaded packs on their backs? This was active learning in its truest sense.

Of particular interest was evidence from the students' comments that the impact of Altitude Physiology lasted long after the end of the class. Students recalled experiences from the Altitude Physiology course in graduate school and even later in professional life. A second take-away from this study strongly supports active learning in translating physiological concepts into clear understanding that bonds with students long after the conclusion of the class. It is apparent that Alma College's Altitude Physiology class was a highpoint in the educational careers of the vast majority of students who responded to the survey. All 35 students indicated that the class was a positive experience and 28 of 35 responded that it was one of their favorite classes. Two thirds of the students responded that the Altitude Physiology class had a "significant positive" impact on their overall Alma College career. These findings, along with other comments and responses, demonstrated that courses modeled after Alma College's Altitude Physiology class are highly likely to be impactful to students both during the class and long after the class is over.

Limitations: Results from the survey administered to students may have been limited by the nominal percentage of participants who the authors were able to contact, i.e., $66 \%$ of the total population. The authors have no way of knowing whether the remaining 50 students not contacted were in some way different from the 100 students who were contacted. Likewise, the study could have been biased by the 36 individuals who chose to respond to the survey. They may represent a group who had a more positive impression of the class and therefore positively skewed the results. Furthermore, the survey results could have been influenced by the time interval between the end of the class and the completion of the survey, which, on average was almost 15 years. It is possible that, in time, participants may remember more good experiences than bad.

Conclusions: The findings of this study are consistent with Stott's [8] findings pursuant to Greenaway's [9] model of potential personal growth. Students who responded to the survey articulated upward growth regarding their ability to conduct, analyze, and present meaningful research. They also verbalized their deeper and broader understanding of physiology as well as their confidence to overcome difficult challenges such as their climbing of Mt. Quandary. The students expressed their outward growth by recalling how their group worked together as a team and how their team coordinated with other teams in order to support each other's research projects. They communicated their inward growth by reflecting how the Altitude Physiology experience helped shape an understanding of who they were and thereby help clarify their future career paths. One student articulated that she sometimes remembered something from Altitude Physiology to guide her through her medical school experience. Finally, the students conveyed their downward growth as they commented about their newfound love of the mountains and their respect for the forces of nature.

For those considering a class similar to Alma College's Altitude Physiology, there are structural constraint and institutional support issues worth considering. Alma College benefited from its spring-term academic calendar that was already a part of the institutional culture at the time when Altitude Physiology was first proposed. In fact, students were required to take at least two spring terms during their academic career and faculty were required to teach a spring-term class every other year. This is not the only workable model, but, in our case, it did provide sufficient time for students to live at high altitude and appreciate the acute exposure and short-term acclimatization.

Travel classes such as Altitude Physiology often necessitate special compliance with college or university rules and regulations that govern off-campus experiences. At Alma, this involved the office of the provost in coordination with the office for off-campus 
studies. These two offices helped the faculty develop an initial course proposal designed to choose a suitable/affordable location, consider travel options, formulate a schedule, identify potential risks, and strategize ways to mitigate those risks. For Altitude Physiology, these risks included those posed by the environment such as excessive fatigue and acute mountain sickness as well as those from the location where emergency access and assistance was limited. Alma College was particularly helpful in providing $24 \mathrm{~h}$ a day/7-days a week "on-call" accessibility for assistance with medical emergencies and crucial communication with parents. Perhaps the most important consideration was the workability of the student research projects. This required much thought regarding how equipment and supplies could be safely transported from Alma, Michigan to the $10^{\text {th }}$ Mountain Division huts near Vail, CO. In our case, this necessitated the services of a very dated snow-cat that hauled our equipment and supplies up the mountain to the huts that served as our base camp. In all, the Altitude Physiology class required significant commitment and planning by faculty members and the institution but resulted in substantial fulfillment of learning objectives by students that carried over for years after completion of the class.

Author Contributions: Conceptualization, M.J.L. and J.E.D.; Formal analysis, J.B.H.II; Investigation, J.B.H.II; Methodology, M.J.L., J.E.D. and J.B.H.II; Project administration, M.J.L.; Supervision, M.J.L. and J.E.D.; Visualization, J.E.D.; Writing-original draft, J.E.D.; Writing-review \& editing, M.J.L., J.E.D. and J.B.H.II. All authors have read and agreed to the published version of the manuscript.

Funding: This research received no external funding.

Institutional Review Board Statement: The study was conducted according to the guidelines of the Declaration of Helsinki, and approved by the Institutional Review Board of Alma College IRB \# R_1CrV4mYTzhvMjhA on 3 November 2020.

Informed Consent Statement: Informed consent was obtained from all subjects involved in the study.

Data Availability Statement: Not applicable.

Conflicts of Interest: The authors declare no conflict of interest.

\section{References}

1. Levine, B.; Stray-Gundersen, J. A practical approach to altitude training. Int. J. Sports Med. 1992, 13, S209-S212. [CrossRef] [PubMed]

2. Chapman, R.F.; Stray-Gundersen, J.; Levine, B.D. Individual variation in response to altitude training. J. Appl. Physiol. 1998, 85, 1448-1456. [CrossRef] [PubMed]

3. Zubieta-Calleja, G.; Zubieta-DeUrioste, U. Space travel in a high altitude environment: Biology by-passing the pressure laws of physics and BioSpace Forming. Cuba. J. Biomed. Res. 2019, 38, 9-18.

4. Zubieta-Calleja, G.R.; Zubieta-DeUrioste, N.M. Space travel in a high-altitude environment: One more step in human BioSpace Forming. BLDE Univ. J. Health Sci. 2018, 3, 97-103.

5. Weigle, D.S.; Buben, A.B.; Burke, C.C.; Carroll, N.D.; Cook, M.B.; Davis, B.S.; Dubowitz, G.; Fisher, R.E.; Freeman, T.C.; Gibbons, S.M.; et al. Adaptation to altitude as a vehicle for experiential learning of physiology by university undergraduates. Adv. Physiol. Educ. 2007, 31, 270-278. [CrossRef] [PubMed]

6. Harper, N.J.; Webster, A.L. Higher learning: Impacts of a high-altitude adventure-based field school on college student development. J. Adventure Educ. Outdoor Learn. 2017, 17, 67-81. [CrossRef]

7. Hattie, J.; Marsh, H.W.; Neill, J.T.; Richards, G.E. Adventure Education and Outward Bound: Out-of-Class Experiences That Make a Lasting Difference. Rev. Educ. Res. 1997, 67, 43-87. [CrossRef]

8. Stott, T.; Allison, P.; Felter, J.; Beames, S. Personal development on youth expeditions: A literature review and thematic analysis. Leis. Stud. 2013, 34, 197-229. [CrossRef]

9. Greenaway, R. In search of respectable adventure. Horizons 1998, 14, 24-26.

10. Cooley, S.J.; Burns, V.E.; Cummins, J. The role of outdoor adventure education in facilitating groupwork in higher education. High. Educ. 2015, 69, 567-582. [CrossRef]

11. Torsney, C.B. The Value of an Outdoor Education Experience. Peer Rev. 2008, 10, 1-2.

12. Allison, P.; Von Wald, K. Exploring values and personal and social development: Learning through expeditions. Pastor. Care Educ. 2010, 28, 219-233. [CrossRef]

13. Baldwin, C.; Persing, J.; Magnuson, D. The role of theory, research, and evaluation in adventure education. J. Exp. Educ. 2004, 26, 167-183. [CrossRef]

14. Beames, S. Critical elements of an expedition experience. J. Adventure Educ. Outdoor Learn. 2004, 4, 145-157. [CrossRef] 
15. Stott, T.; Hall, N. Changes in aspects of students' self-reported personal, social and technical skills during a six-week wilderness expedition in Arctic Greenland. J. Adventure Educ. Outdoor Learn. 2003, 3, 159-169. [CrossRef]

16. Kuh, G.D. High-Impact Educational Practices: What they are, Who has access to them, and Why they matter. Liberal Education and America's Promise (LEAP); Association of American Colleges and Universities: Washington, DC, USA, 2008.

17. Goodman, B.E.; Barker, M.K.; Cooke, J.E. Best practices in active and student-centered learning in physiology classes. Best Pract. Act. Stud. Cent. Learn. Physiol. Cl. 2018, 42, 417-423. [CrossRef] [PubMed]

18. Driscoll B., A. Graduates' perspectives regarding the impact of the integration of experiential learning in academic programs. Masters Thesis, Iowa State University, Ames, IA, USA, 2011.

19. Mogk, D.W. Undergraduate Research Experiences as Preparation for Graduate Study in Geology. J. Geol. Educ. 1993, 41, 126-128. [CrossRef]

20. Kinkel, D.H.; Henke, S.E. Impact of Undergraduate Research on Academic Performance, Educational Planning, and Career Development. J. Nat. Resour. Life Sci. Educ. 2006, 35, 194-201. [CrossRef]

21. Nagda, B.A.; Gregerman, S.R.; Jonides, J.; von Hippel, W.; Lerner, J.S. Undergraduate student-faculty partnerships affect student retention. Rev. High. Educ. 1998, 22, 55-72. [CrossRef]

22. Michael, J. Where's the evidence that active learning works? Adv. Physiol. Educ. 2006, 30, 159-167. [CrossRef] [PubMed] 